\title{
Lusotopie
}

Recherches politiques internationales sur les espaces

issus de l'histoire et de la colonisation portugaises

XVI(2) | 2009

Afrobrésiliennité ? Luso-afrobrésiliennité ?

\section{Angola 2006: a British Parliamentary Visit}

Angola 2006: Uma Visita Parlamentar Britânica

Angola 2006: Une visite parlementaire britannique

\section{David Birmingham}

\section{OpenEdition}

Journals

Electronic version

URL: http://journals.openedition.org/lusotopie/173

ISSN: 1768-3084

Publisher:

Association des rechercheurs de la revue Lusotopie, Brill, Karthala

Printed version

Date of publication: 1 June 2009

Number of pages: 221-243

ISSN: 1257-0273

Electronic reference

David Birmingham, « Angola 2006: a British Parliamentary Visit », Lusotopie [Online], XVI(2) | 2009,

Online since 02 October 2015, connection on 27 January 2020. URL : http://journals.openedition.org/

lusotopie/173 


\section{ANGOLA 2006: A BRITISH PARLIAMENTARY VISIT}

In 2006 the author acted as interpreter for a small party of British politicians who visited Angola. His own account of the expedition highlighted the then prominent questions of agriculture and rural development, of the empowerment of women in urban communities, of perceptions of national identity and the role of electoral politics. The effect of rising and falling oil wealth on legitimate investment and on corrupt embezzlement had to be delicately addressed as did the balance between presidential power and opposition newspapers. To many Angolans the thriving Pentecostal churches seemed as important in their daily lives as the non-governmental development agencies or the cash-strapped government ministries of health and education. In 2006 the first signs of China's new interest in Africa were beginning to match the entrepreneurial dominance of Brazil and Portugal and eclipse the regional aspirations of South Africa.

\section{Angola 2006: Une visite parlementaire britannique}

En 2006, l'auteur a servi d'interprète à un petit groupe de parlementaires britanniques qui s'est rendu en Angola. Son compte rendu de mission soulignait les questions alors primordiales de l'agriculture et du développement rural, des droits des femmes dans les communautés urbaines, de la perception de l'identité nationale et du rôle de la politique électorale. Il a fallu aborder la question de l'effet de la hausse et de la baisse de la richesse pétrolière sur les investissements légitimes et sur la corruption et le détournement de fonds avec beaucoup de délicatesse, tout comme l'équilibre entre le pouvoir présidentiel et les journaux d'opposition. Pour de nombreux Angolais, les églises pentecôtistes prospères semblaient aussi importantes dans leur vie quotidienne que les agences de développement non gouvernementales ou les ministères gouvernementaux de la santé et de l'éducation à court d'argent. En 2006, les premiers signes du nouvel intérêt de la Chine pour l'Afrique commençaient à rivaliser avec la prédominance entrepreneuriale du Brésil et du Portugal, et à éclipser les aspirations régionales de l'Afrique du Sud.

\section{Angola 2006: Uma Visita Parlamentar Britânica}

Em 2006, o autor serviu de intérprete a um pequeno grupo de políticos Britânicos, que estavam de visita a Angola. O seu próprio relatório da viajém destacava as questões, então, proeminentes, no domínio da agricultura e do desenvolvimento rural, da promoção do estatuto da mulher, no seio das comunidades urbanas, da percepção da identidade nacional e do papel da política eleitoral. Foi necessário abordar, de maneira bastante cuidadosa, a questão do efeito das subidas e descidas da riqueza petrolífera sobre os investimentos legítimos e sobre a corrupção e os desvios de fundos, bem como o equilíbrio entre o poder presidencial e os jornais da oposição. Para muitos Angolanos, as prósperas igrejas Pentecostais pareciam ser tão importantes no seu quotidiano como as agências de desenvolvimento não-governamentais ou os ministérios governamentais da Saúde e da Educação desprovidos de dinheiro. Em 2006, os sinais do novo interesse da China por África começavam a questionar o domínio empresarial do Brasil e de Portugal e a eclipsar as aspirações regionais da África do Sul. 
$I_{p}^{n}$ 2006 a small party of British politicians visited Angola. Their perception of the country's post-war development requirements will make an interesting baseline from which to measure national success and failure over the following three years. The questions they explored ranged extremely widely over issues of municipal governance, provincial devolution, child protection, peasant farming, Chinese investment, economic transparency and other issues highlighted in this unofficial paper written at the time, that is three years ago, by the team's British guide and interpreter. Being politicians the visitors were naturally interested in elections. Their enthusiasm, as this paper hints, was not matched at the time by all Angolans, many of whom remembered the brutal urban warfare which broke out after the parliamentary and presidential elections of September 1992. Debate focussed at the time on two issues. One was whether it was possible, in a country some of whose population lived in under-administered and inaccessible provinces, to honestly register voters in a comprehensive fashion. The other was whether the electoral commission should risk another winner-takes-all election for the presidency or whether it should limit the electoral exercise merely to the choosing of a new parliament. In the event the registration of voters appeared to be carried out with reasonable efficacy and probity. On the other hand the decision was cautiously made, as anticipated, not to risk putting up for election a president who had been in post since 1979 and had been elected with a slightly less than absolute majority in 1992. A potential crisis such as that which broke out in Kenya, or in Zimbabwe, where electors attempted to change not only the composition of parliament but also the real holder of power in the presidential office, was averted in Angola. Avoiding a winner-takes-all election with the presidency at stake lowered the electoral temperature while at the same time giving Angolans an opportunity to vote, to feel that they were real citizens, to begin to sense ownership of their society. The most prominent leader of the defeated opposition accepted with equanimity the September 2008 election result which gave the government some 80 per cent of the votes. He reassured his followers that democracy would continue to grow in strength and that another opportunity to vote would occur at the next election. The scale of the parliamentary victory by the ruling party may even have encouraged the palace to think that a presidential election might not be as risky as the courtiers associated with the ruling dynasty had feared. ${ }^{1}$

Fuly 2009

\section{The Question of Election}

The first question which any political visitor to Angola will ask of his or her hosts is "how are the plans for a general election proceeding?". The technical answers come from a variety of foreign agencies anxious to facilitate the complex task of registering voters in a land without a census in which about four million people have had to flee from war, often leaving all forms of identity document to burn in their abandoned homes. Creating a new register is supposed to be undertaken between November 2006 and May 2007 but as an opposition spokesman pointed out this was largely a rainy season in which most mud paths and tracks will be impassable. Since the 2002 ceasefire elections have always been "two years down

1 The official All-Party Parliamentary Group for Angola. Observations and Recommendations on a Visit to Angola in September 2006 was published by Chatham House, London, and was a sequel to a report relating to a similar visit in May 2003. The present author wishes to thank Elizabeth Donnelly and Manuel Paulo, of Chatham House, who made this parliamentary visit not only possible but also enjoyable. 
the line" and at the moment that is still the common opinion. Debates about the election so far have had more to do with the hours of opening of polling stations than with the questions of substance such as should parliamentary and presidential elections be sequential (as the government will probably decide) or simultaneous (as the opposition expects and prefers).

Technicalities are not the only problem. Elections in Angola generate fear. The one and only general election ever held in Angola, in September 1992, was followed by terrible bloodshed and the half of the population old enough to remember that far off day still shudders. Indeed, in some communities people are not yet rebuilding their homes with permanent materials as they are "waiting for the elections". In 1992 the winners, rightly anticipating that the losers would go back to war in the restless provinces that had so long been economically neglected, had trained up an urban paramilitary force to root out and kill opposition sympathisers in the city. The country exploded and two years of slaughter and destruction exceeded anything witnessed in either the colonial war of 1961 to 1974 or the war of international intervention of 1975 to 1991. The return of such violence after a new winner-takes-all election remains an anxiety down in the slums and up on the farms.

A return to war is not likely, though the possibility should perhaps not be ruled out while rural rebirth remains so slow and urban poverty remains so acute. The peace of Bicesse in 1991 was not a truly indigenous settlement between the two armed sets of economically ambitious bourgeois politicians of the highland and the coastland but rather a ceasefire imposed by Russia and America at the end of their Cold War. It did not share out the political opportunities and the economic spoils equitably and was therefore never likely to last, though foreigners at the time did not perceive the weaknesses. The peace of Lusaka in 1994 was an equally foreign attempt to end the civil war but the leader of the opposition did not even turn up to sign the accord so ashamed he was of having to pause in his search for power through the barrel of a gun. The Luena peace of 2002, by contrast, was an internal political agreement, signed not far from the grave of Unita's totalitarian dictator in a land at the end of the earth which the government had scorched into submission. Surviving officers of the opposition were now able to join those who had changed sides five years earlier to seek fame and fortune in the cities of the oil-rich coast. They negotiated minimal resettlement grants of tools, utensils and small cash payments for their demobilised guerrillas.

The peace of the Luena protocol now needs to be sustained. Angola's population now needs to see the benefits of peace, the economic dividends of peace. The restitution of lost assets, the psychiatric rehabilitation of child soldiers, the repair of broken communities, all need to be tackled. One civil society worker described the great fear as the fear of neglect. Once the government has garnered the votes it might assume it has received a mandate to pursue existing policies with impunity. For those Angolans who have not yet seen the dividends of peace, elections could lead to quite dangerous disappointments.

A more enthusiastic attitude to elections comes from existing parliamentarians, both those who have joined the unequal "coalition" of national unity and from the tiny "irritant" parties of whom ten hold 20 seats between them (as compared 
to the 200 held by the MPLA and the 70 by Unita). No dispassionate observer seems to think that an election would be likely to significantly alter this balance of power, but the government does seem reluctant to test the matter. Wealth and influence depend on climbing aboard the establishment bandwagon and opposition parties have but a single declared platform, to oppose the personalities but not the policies of the current regime. Visitors could detect no policy differences between government and opposition parties, merely leadership differences and some regional bids for access to the central pork barrel.

Lethargy is much more widespread than vivaciousness among prospective voters. Some, such as the Jehovah's Witnesses, say officially that they will register as electors if they are required to do so but that they will not vote. One of the questions asked, but not answered, is whether the faithful who flock to the new Brazilian-run and American-funded Pentecostal churches mushrooming all over Luanda will take part in the election. On the Sunday before our visit the Universal Church of the Kingdom of God had rented both of the main city stadia for prayer meetings (one holding 80,000 adherents and the other 20,000) while the Catholics had organised a pilgrimage in busses, cars and even helicopters to take 70,000 people to the shrine of Our Lady of Muxima in a seventeenth-century chapel on the far side of the Kwanza River. Religious ceremonies, and their powers of healing, are of far great importance to ordinary men and women in the street that any election. Stories of miracle cures in the evangelical stadium get press coverage while the Papal Nuncio tells proud Catholics that the "miracles" performed by the late Father Leonardo Sikufinde in the remote Cunene province are being checked by the Vatican with a view to canonising the first Angolan saint. In such an atmosphere it seems unlikely that the ordinary punter will flock to the polls as he and she did in 1992. Only middle-class intellectuals talk of an election as putting the seal of legitimacy on peace, though the Minister for Territorial Administration did courteously ask his British parliamentary guests for help in planning Angola's elections. Election advisory organisations in both the United States and South Africa do, however, already seem to have one toe on the ground in readiness to help.

\section{Unita and MPLA}

The only opposition party with any substantial presence in parliament, and in the quasi-power-sharing government, is Unita. The delegation was unable to meet the party president but we were cordially received in the small party headquarters up a dusty blind alley in one of the Luanda municipalities. We had been warned that it was difficult to pin Unita spokespersons down to discussing issues - "the opposition is a policy-free zone" we were jocularly advised - and sure enough the only topic that the vice-president wanted to talk about was the holding of elections and election timetables. Unita is very proud of the fact that its new leader, Samakuva, was elected by a party congress whereas the MPLA leader has been in post unchallenged since 1979.

The traditional heartland of Unita support is on the central highland. We were shown one of the bunkers from which Jonas Savimbi commanded his platoons during the civil wars. The site is marked by a parked tank rusting in the grounds 
of the veterinary school. We drove past the city offices of Unita but they appeared very closed, perhaps because we had arrived on yet another bank holiday. Not everyone remembers Unita with much fondness, however, and one attempt at political mobilisation led to party militants being drummed out of town. The great fear of many old enough to remember 1992 is that whoever loses the next election will take a leaf out of Unita's book and try to reverse the result by force of arms as happened after the last election. Nowhere on our travels did we meet much enthusiasm for another attempt at an election, particularly a first past the post, winner takes all, election.

For some, at least, of the old Unita generals gaining access to the free-market band-wagon is a more important priority, and a better way to wealth-sharing if not power-sharing, than trying to mount an election. Unita, and to a lesser extent MPLA, is essentially an old fashioned single-platform liberation movement and when independence had been achieved the only issue was who was going to be the president replacing the plumed governor-general of colonial days. Elections in Africa tend to be beauty contests rather than debating forums. In some ways Angola is very un-African and political culture tends rather to mimic Portugal and Brazil, but the cult of personality is nevertheless deeply entrenched and framed portraits of the president in his prime ornament every government office.

The facilities available to the MPLA are much more palatial than those of its opponent. The shiny multi-storey party headquarters in Luanda were allegedly given to the country by Tito of Yugoslavia. The spokesperson who received us said that 1,100 people worked for the party there but on a part-time basis so that their salaries were paid for by other institutions and did not become a burden to the party itself. What all these people did was far from obvious and preparing for an imminent general election did not seem to be on the agenda.

- "Oh, yes we have everything arranged for the voter registration which will begin in November and be completed by May 2007, no sweat.

- Then, why will the election not take place in 2007?

- Oh that will not be possible because voter registration will take place during the rainy seasons when the roads are closed so there may be serious delays in voter registration.

- And will the presidentials take place at the same time as the parliamentary election?

- Oh we have yet to decide that."

Urgency and consistency seemed lacking.

\section{Broadcasting, Publishing and the Media}

Members of parliament in Britain are addicted news junkies. They naturally took a keen interest in the media scene in Angola. On the highlands, in Angola's second city of Huambo formerly known as New Lisbon, news is scarce. The national government is so fearful that disaffection in underdeveloped rural provinces might once more lead to peasant wars such as those seen in the 1980s, that it has effectively forbidden any broadcasting by independent radio stations. In the far south, at Lubango, beyond the range of the civil war, one local radio does 
operate, and another broadcasts to the ancient coastal city of Benguela. The most important independent radio, however, is the Roman Catholic Radio Ecclesia. Despite heavy investment in provincial studios and FM repeaters, for which the British government gave some financial help, the Angolan government has banned their use. When Radio Ecclesia tried to experiment with its relay station in Huambo it was closed down by the police within a week, presumably on the orders of the presidential palace in Luanda.

The highland development agencies - with a little Swiss funding and knowhow - have facilitated the publication of a ten-page monthly "news bulletin" with a circulation of 3,000 in one of the city municipalities of Huambo. The content is fairly moralistic and the news tends to be family-oriented (commune welcomes safe delivery of triplets to proud local mother) but any news is so scarce that the bulletin is passed from hand to hand around the whole district and indeed beyond. The independent but very expensive newspapers of Luanda, of which more below, do not reach the provinces and even the bi-monthly news magazine put out by the Catholic Church appears to have a limited rural distribution.

One issue of great interest to the visiting parliamentarians was the place of women in the spectrum of power and politics in Angola. By serendipitous good fortune one of the independent newspapers, the Angolense now in its seventh year of publication, carried a front page article on the day of our arrival which discussed the pecking order of the ten most influential female entrepreneurs in the country. The top spot was held by Ana Paula dos Santos, the wife of the state president. In second place came Isabel dos Santos, the British-educated daughter of the president's first - Russian - wife. She has long been a major player in the field of diamond marketing and it may have been in part to protect her interests that Angola signed up to the Kimberly process of diamond verification in a De Beers-led attempt to stop "blood diamonds" from bringing gems into disrepute. More recently Isabel has been very active in the field of telecommunication investments. Third place is held by Albina Assis, a member of one of the grand old Luanda families. She once held the key post of minister of petroleum and is the only woman to serve on the president's privy council.

Another insight into the role of women arose when the British delegation were invited to visit the ministry of foreign affairs. They were received by Mademoiselle Neto, the daughter of Agostinho Neto who had once been Amnesty's first prisoner of conscience and the honorary president (in incarcerated absentia) of the MPLA. On his release he became the commander-in-chief and paymaster-general of MPLA's guerrillas and on 11 November 1975 emerged as the country's first state president. His daughter, although not a member of the thirteen families that have reigned over Angolan high society for the last dozen or so generations, is now a vice-minister is the Dos Santos government. This seemed the ideal occasion for a media photo opportunity but the British delegation was eclipsed by a more important delegation from Equatorial Guinea which was visiting on the same day. $^{2}$

2 The quotations in this article are culled from the weekly Luanda newspapers of 16 September 2006. 


\section{Microcredit and the Dynamism of Informality}

The informal economy of Angola is probably the most dynamic in the world. One example of this was witnessed in the São Paulo district of Huambo city. Under the Portuguese the district was one of the city's two industrial zones but the expatriate managers fled the country in July 1975 at the approach of the western armies of intervention, dressed in the apartheid fatigues of the South African army. Local people, deprived of their colonial wages and terrified of the insecurities of war, turned on the factories and warehouses and robbed them of their stock, their furniture, their plant, and any moveable items that might conceivably have a marketable value. Recovery was very slow and in 1992 the area was once more in the eye of the whirlwind. A dismayed party of opposition, Unita, had been assured by the United States that if it laid down its arms and took part in an election supervised by the United Nations it was bound to win the power which its leader had craved ever since his student days in Switzerland. The American advice proved to be wrong, however, and the majority of Angola's people feared the populist Jonas Savimbi even more than they feared the technocratic Eduardo dos Santos. The enraged psychopath took his revenge on the city of Huambo with heavy artillery during a third civil war. And still the people, served by their informal economy, survived.

In August 2006, three weeks before the British parliamentary delegation visited the city, the urban planners of the ruling party - steeped in the tidy-minded bureaucratic traditions of Portugal - decided that the seething and teeming hundred-acre market of Huambo city was an eyesore. Never mind the struggling people, the daily shoppers, the war-time survivors, the market-garden retailers, the textile saleswomen, the children earning their school fees by selling sticks of chewing gum, the market was bulldozed and all that remained for the visitors to see was the occasional plume of smoke arising from the ashes.

An association of market women, supported by a microcredit scheme supervised by the Development Workshop, was asked to comment. Well, they said, there was some hullabaloo - confusão - and instead of walking to market every morning we had to pay the fares on the VW microbuses to the new market-site five kilometres out of town. "But we mobilised ourselves, we arranged a network of informal satellite markets throughout the city and near to our customers". Mere politicians will never be able to keep Angola's market women down and those customers whom we met confirmed that after three weeks of confusion transport, distribution and supplies were almost back to normal. Most of those participating in the microcredit project are women. Women came to shoulder heavy economic responsibilities as well as the family ones when caught up in the wars. Their responsibilities seem not to have lessened and yet there remain many barriers hindering the participation of women in institutionalised political and economic life.

Members of the DW microcredit union were asked for their experience of the agency. "We can get loans of up to one thousand dollars to set up small businesses." One woman had set up an import business for spare parts - very necessary in a city where the roads are shot to hell and virtually all the municipal busses land up in the corporation graveyard after barely two years of service, and all for want of spares. Other women went into more traditional pursuits such as 
retail clothing, thriving on a credit system in which interest rates are a mere three per cent. But how, asked our MPs, is repayment guaranteed. Ah, was the reply, we belong to lodges of a dozen or so members each and the system is self regulating. None of us can afford to let a fellow member default and bring the system down. And when it comes to an election will you vote Unita or MPLA. "Oh, I shall vote for the Development Workshop."

Once more the question arises as to for how long will the system need the umbrella of an international agency to ensure probity and protection from those who might like to "formalise" the profitable retail sector of the economy. It is good question. The advice we were given is that the next three years will be crucial in deciding if Angola comes out of its post-civil-war trauma with a vibrant and confident civil society or whether disillusion will creep in and political instability break out. Development Workshop officers are optimistic and think that the microcredit schemes they have initiated are now ready to stand on their own feet. One KixiCredito microfinance group will be independent of international donor support by 2007.

\section{Sita José fiddles while Rome burns}

On 20 September 2006 the Fornal de Angola, the government-owned daily, ran a double-spread photograph of the Giant Sable Antelope. The photograph was an old colonial one, belonging to the days when Portugal hoped that one day Angola might become a tourist destination and its very rare antelope was the poster symbol of imperial pride. The dream lives on and Sita José, minister for planning, land tenure and urbanisation, was hosting an international conference on sable antelopes in the little up-country town of Malange at the head of Luanda's rickety Victorian railway. It was long assumed that the last giant sable had been eaten during the fourth civil war of 1998-2002 when the armies of each of the liberation movements (which stand in lieu of political parties) tried to starve out their opponents. Famished conscripts had survived on anything from bush meat to wild honey. Since the war ended it is alleged that one baby sable has been seen, or even that a herd of thirty animals has been filmed by scholars associated with the Catholic University of Luanda.

The minister, meanwhile, is at the heart of the planning exercise which aspires to return Angola to the tidy-mindedness of yesteryear. On a recent visit to London he laid out his vision for cities in which everything is neatly zoned, a bit like the pale, bloodless, soulless, city of Brasilia a thousand miles up-country from the vibrancy of Rio de Janeiro across the Atlantic waters from Luanda. People do not feature in the new Angolan plans and neither does economic reality. The ministry does not recognise that Angola is almost the poorest country in the world, lying as it does at the bottom of the Human Development Index with a 260 per thousand child mortality statistic. Angola can only survive the next decade by nurturing its wonderfully dynamic and flexible informal economy which has its own codes of conduct and rules of engagement. And Angola's people will only invest in the future if their assets of land and housing are guaranteed quickly and efficiently rather than threatened by new concepts of territorial zoning and planning. 


\section{Chinese neo-imperialism}

We were advised that we should see Chinese "swarming" everywhere in Angola but we actually saw few Chinese at work since our week was hit by two bank holidays - the birthday of the poet-president who led Angola to independence in 1975 and died in 1979, and the 94th anniversary of the highland workshops of the Benguela Railway which later hosted the garden city of Huambo. We did not fail, however, to ask about the dramatic new phenomena which the Chinese arrival represented. In Huambo one of our British parliamentarians was temporarily taken ill and a Chinese fellow guest at the inn kindly suggested that we take him to the clinic.

- "Do you mean the provincial hospital which is being refurbished by Chinese technicians and civil engineers?

- No, no, no, I mean the private clinic run by the Angolan National Oil Company and to which all middle class people go for proficient but very expensive treatment."

Chinese charm impersonated... The return of the Chinese to Central Africa is quite largely linked to the need to rebuild the infrastructure of transport with all speed. In the nineteenth-century the French used Chinese workers to build the Congo railways to Brazzaville while the British preferred Indian labour to initiate the building of the Benguela railway to the Belgian copperbelt. Chinese engineers, navvies and capital are now being used not only to rebuild the Benguela railway - in the hope of linking Huambo to the ocean during the course of 2007 - but also to re-open the Luanda railway through the old coffee groves of the forest zone. Even more dramatically the Chinese civil engineers hope to rebuild the road network linking north and south and put in new bridges which can carry heavyduty trucks.

One problem of the Chinese programme is that it will create very few new jobs for Angolans who suffer from acute levels of unemployment and underemployment. The contracts specify that 70 per cent of the input of staff and capital shall be Chinese and only 30 per cent local. When leaders of Unita were asked about the Chinese programme they said "we love it; if anything can cause the MPLA to lose the next election it is the dismay caused by seeing Chinese labourers doing jobs which Angolans would be perfectly capable of doing". The matter, however, is not quite as simple as that. The productivity of the Chinese road gangs is very high. By contrast one Angolan building team to whom we talked consisted of a foreman and six labourers equipped with a tape-measure, a spirit level and a mattock and each person seemed to take it turn to work while the others commented, debated and discussed the inputs and outcomes relating to a donor-financed reinforced concrete water cistern on hospital premises.

The rapid development of infrastructure by the Chinese is also potentially problematic because there is little political conversation at the local level. People seem not to be involved at any level of planning. The best location for a road or a pipeline is not decided by the people who live nearest but by remote bureaucrats. On the other side of the coin, however, the Chinese live at a domestic level of comfort - or discomfort - which is much closer to that of their African neighbours 
than is that of the western expatriates who live increasingly fear-ridden lives entombed in razor-wire barricades. The Chinese managers, moreover, learn good Portuguese before coming to Angola which is not always true of Anglophone expatriates who tend haughtily to expect their Lusophone opposite numbers to learn English.

We were unable to discuss the question of Chinese clothing which has been so controversial in the European Union. We were told, however, that the Angolan textile and clothing industry has failed to revive owing to the large-scale importation of second-hand western clothing which is hawked down every alley and by-way and sold from the central reservation of urban streets in which the moneyed classes spend much of their day stranded in traffic jams of monumental proportions. When the time comes to pay China for its multi-billion dollar lines of credit most of the payment will come from oil but one assumes that a market in manufactures - which inevitably depresses local productive initiative - is likely to be part of the agreement.

\section{Save the Ghildren}

Half of Angola's twelve or more million people are children below the age of fifteen. They have had a raw deal. Among girls three quarters of their time is spent in domestic or commercial work whereas the slightly more privileged boys gain better access to schooling and only spend one quarter of their time on home chores or street trading. The traumas of war, the intellectual consequences of malnourishment, the loss of parents mown down by cholera or TB, and weakened immune systems ravaged by HIV, all take their toll on child welfare. Against this background one of our most heartening experiences was quietly sneaking into the hall behind the great Methodist church in Luanda to listen to a choir of sevenyear-olds singing their hearts out in Portuguese, Kimbundu and - rather more surprisingly - Kikongo.

One of our hosts and sponsors was the British Save the Children Fund. They took us to see the way in which street theatre is being used in Angola to heighten AIDS awareness. Young adolescents, watched by their juniors as well as their seniors, dramatised the nature of courting, the pressures which older men with money and status put on school girls to have clean sex with them, the risks of unprotected intercourse, and the proper way of rolling on a condom. British politicians were fascinated by the vitality, energy and humour of the acting. One of the messages which was put across was that HIV infection is not something that takes place "out there" in the big bad city, or among immoral foreigners coming across the borders, but something that we have here in our rural midst. No one knows what the infection rates are in Angola but the official figure of about $4 \%$ is probably an underestimate. Three years ago a figure of $8 \%$ was based on the maternity statistics of Luanda hospitals.

Protecting children also involves protecting parents and the Save the Children staff in Huambo took us to the HIV unit attached to the provincial hospital. The testing and counselling room has scarcely room for a desk and two chairs but is staffed by a Catholic nun who is a qualified doctor. She interviews about seven people a day (from a population of over a million in the province) and sometimes as many as two of them turn out to be HIV positive. The fund is financing the 
building of a purpose-built annexe to the hospital and one can but hope that it will be as intensively used as the cramped old premises and not become another of the dream projects with which Angola is littered. In Luanda a shining new AIDS research facility has been built but has no staff to run it.

\section{Gapacity Building}

Visiting the oil companies, both the harbour facilities of the state's Sonangol and the borrowed De Beers offices used by Britain's BP, brought home to us just how scarce qualified personnel are in Angola. The obvious shortage is of staff who can communicate with the wider world in English when Angola is a closed enclave of the Lusophone world. But more critically, Angola does not have the capacity to train and educate its people. The Agostinho Neto University has a course in engineering, but this produces only 40 graduates each year. Angola's oil and diamond extractive industries only employ one per cent of the country's population and yet personnel is acutely scarce and Angola has a catastrophic deficit in human capacity. Oil company personnel have often been trained in Anglophone southern Africa with the technical courses available in Durban being a favourite. But it is not only technical qualifications which are scarce. All forms of private and public administration run very slowly - a former employee of the Aberdeen chamber of commerce had to spend two hours just paying the bill for his rental car. International companies, non-governmental agencies, government ministries, the four great oil companies, all try to poach each others' competent middle level managers to meet the requirement to Angolanise.

Providing a salary, accommodation, medical insurance and travel for an expatriate in Angola is expensive, at least $\$ 600,000$ per annum. The country's dozenodd private institutions of higher education have by and large no permanent staff - and sometimes no permanent premises either - but they buy in hourlypaid teaching from across the whole range of available expertise, both Angolan and expatriate. One of the exemplary British projects in Angola is the Crown Agents' scheme to improve the takings of the Luanda Customs House. Efficiency and probity are the new concepts that have been introduced - despite some early foot-dragging by those who might otherwise have hoped to take a cut by "facilitating" clearance through the revenue agencies. More inputs are needed, however, and although revenue is now much improved speed is not. The oil companies - who have built their own half-mile of new dock-side quays on reclaimed land - have privileged priorities but other import-export businesses are accustomed to waiting weeks or even months to gain access to their shipments. This is a serious disincentive to foreign entrepreneurs and investors. So too is the lack of bureaucratic competence in the government offices which still have to issue fourteen different licences before a company can be registered. A World Bank record in obstructionism we were informed.

\section{No Representation without Taxation}

In countries such as Angola where revenue is centrally collected, from customs duty or oil royalties, and not paid by citizens out of income, there is very little popular pressure on government to improve services or else beware of voter wrath. 
Hence the clever inversion of the Boston tea party slogan that one hears in Africa: no representation without taxation. The idea that the government is not accountable to the people is one that British parliamentary visitors find completely baffling. In Angola you do not need to curry favour with income tax payers because, to all intents and purposes, there are no income tax payers. Ninety per cent of government revenue comes from the oil companies direct (give or take a little leakage which strict government rules of confidentiality try to mask). Although the government is gradually increasing public spending, with current spending on health and education reaching 75 dollars a head, the preferred development model is for prestige projects such as the Sonangol building from which ordinary Angolans will see very little immediate benefit.

The question of political responsibility becomes even more difficult to grasp when members of the British House of Commons (and even those in the Lords) have to recognise that no Angolan has a member of parliament to whom he or she can turn for redress in the event of government malpractice. Voting in Angola - as in the European Union - is by party list which effectively means that all MPs are anonymous. None can be lobbied and none can be de-selected. Members of the national assembly are beholden to their party managers rather than to their multi-member constituencies. A member of a civil society group noted that in Angola there are no citizenship rights, there are only "constitutional rights", but nobody knows what these constitutional rights are. As national assembly members are apparently unaccountable to ordinary citizens, it is necessary to ask the question: who will protect the rights of Angolans?

The matter of political accountability became even more bizarre when we moved from interviewing constituents to interviewing the speaker of the Angolan parliament. He assumed that his role was to defend the government record rather than defend the interests of grass roots citizens. He took this responsibility very seriously and gave us an intelligent eight-point plan of action for the MPLA (without, incidentally, mentioning its sleeping coalition partner which provides a few Unita ministers or vice-ministers and one or two provincial governors). Roberto de Almeida did not see himself as the people's watchdog in the way that his guests had anticipated that he would.

\section{Centralisation and Decentralisation}

Travelling through the country enabled us to realise just how subtly subversive the concept of community development is in a country which has experienced a hundred years of tightly centralised government by the freemasons of the Portuguese republic, by the Catholic generals of the forty "fascist" years, by the ideologues of the Marxist command economy and now by the proponents of what the Economist Intelligence Unit's erstwhile correspondent wickedly called "jungle capitalism". Everyone in Angola who needs resources now looks not to his or her provincial governor, nor to his or her departmental minister, nor even to the office of the ever-changing prime minister, but to the palace, the Futungo de Belas, where the state president has his offices. That is where budgets are finally decided. During a lively visit to the faculty of agriculture's research station in Huambo we asked about the budget and were told that it had been fixed for 2007 at the same 
cash level as for 2006. This means a cut of about 15 per cent in real terms. We were also led to believe that other social budget heads such as health and basic education were not likely to match - let alone exceed - the current level of inflation.

All talk of decentralising the system may yet be a premature. If an election were to be called, for instance in 2008 after a gap of sixteen years, decentralisation would be a popular platform. But the fear is regularly expressed that decentralisation is merely a policy to blind foreigners into admiration and that once the election has been held the hundred-year-old tradition of centralised power would quickly be restored.

The Ministry for Territorial Administration is responsible for both the reform of local administration and for the preparation of election procedures. No local autonomy has been attempted since the impact of war, the lack of infrastructure, and the absence of any historical precedent made devolution seem impossible. The provinces are run in true colonial style by "governors" appointed by the president. The ministry's aim is fist of all to "consolidate" this centralised administration and only then to risk devolving any share of power to regional bodies. United Nations agencies and non-governmental organizations nevertheless continue to advocate the introduction of local government, at least in the municipalities. So far the government's commitment to decentralisation is targeted on "selected" municipalities. This promised trial, however, will only be initiated after the long awaited parliamentary and presidential elections have taken place.

\section{Publish What You Pay or the Extractive Industries Transparency Initiative}

If the oil industry in Angola is secretive, the diamond industry is ultra-secretive, and all other extractive industries are but a distant memory of Portuguese colonial myths. (The latest hot gossip says that work has stopped on the $\$ 2$ billion new airport because the Chinese front-end loaders discovered that they were digging up diamonds; such stories were always rife in Portuguese days as people dreamt of quick riches.) Until recently the government was very keen to hold on to the tradition of secrecy and even now BP is quite cautious about revealing figures to inquisitive members of parliament. It once burnt it fingers badly by trying to push the door of openness a little harder and faster than rival oil giants (or African regimes) were willing to tolerate. Now, however, it is public knowledge that a licence to explore in one of the deep-water blocks cost about $\$ 1,000$ million dollars and that a community development supplement of about $\$ 100$ million is added to each licence.

Chevron pioneered the concept of putting some of its resources into community development projects and BP is following the same line on a smaller scale. This does raise the serious philosophical question as to whether private investment in community development allows government to play down its own responsibilities. Should not oil royalties to the ministry of finance be used more extensively for development policies rather than held back for use in priorities dear to the elite. In the past the problem of underfunding programmes for the poor was compounded by leakage of oil revenues from the public purse to private 
pockets - one former IMF assessment put the leakage at $\$ 800$ million dollars a year - but transparency has greatly improved since then. Still, however, the presidency prefers to obtain expensive credit from China with no strings attached rather than meet the conditionalities of the IMF in the hope of cheaper loans. But if transparency has been improved on the signature bonuses with their community development supplements the same cannot be said of the profit sharing arrangements.

\section{Land Mines and Unexploded Ordinance}

Several districts in Angola are full of landmines. During the times of war eleven armies laid landmines across Angola and virtually none of the mine-fields was mapped to facilitate post-war clearance programmes. Nor is there any prospect that the armies that laid them will be willing to help finance the huge cost of identification and destruction of mines and other ordinance.

In 2003 an all-party group from London visited the remote Moxico province and spent half a day with MAG, the Mines Advisory Group, witnessing the skill and professionalism of Angola's mine disposal experts some of whom had learnt their craft in places as far away as Cambodia and Afghanistan. Destroying ordinance is an expensive business and if any help is required in securing the future funding of MAG or other operations it should urgently be given.

The 2006 visitors were shown the installations of the Halo Trust by its Scottish commander-in-chief and once again were hugely impressed by the professionalism of the operation and overwhelmed by the magnitude and cost of the task still ahead. Funding is now largely carried by Angola's own budget with a great improvement in efficiency since external funding by the European Union and the United Nations had proved to be laboriously slow. Halo is responsible for four provinces one of which contains some of Angola's prime agricultural land. Progress on the land-mine front, like progress on the community development front, was distinctly cheering.

\section{The Luanda Chamber of Commerce and the Angola Agency for Private Investment}

The two business institutions which we visited presented a rather sharp contrast to one another. The chamber of commerce, a shabby office up two sets of wellworn colonial stairs, perplexed our parliamentarians. Perhaps this was the voice of the marginalised, even perhaps the voice of businessmen affiliated to parties of the opposition. But no, their office was in an old ministry of the interior government building which they shared with the fiscal police, the arm of government which tries to restrict, or benefit from, the informal market sector. The chamber has affiliated members and is even linked to small business cells in the provinces. But when overseas investors were asked about the Luanda chamber of commerce they coyly suggested that it was an institution which they preferred to by-pass.

The agency for private investment presented a totally different image. The premises were centrally located and ultra-modern, the chairman was as sharply suited as any state president, the information was impeccably presented by power- 
point using the most expensive technology. Money swills about in Luanda with unbelievable opulence and the delegation were deeply affected by the contrast between the musseque quarters in which real people live and the mirrored corridors of power of which the investment agency was a prime example.

\section{Food Security}

"There are countries that do not have diamonds but which are better off than we are because they have agriculture." Agriculture was often spoken of as Angola's silver hope. The current food deficit is 54\%, and imported food puts an increasing burden on the cost of living of struggling people. Agriculture could provide jobs for millions of unemployed and underemployed Angolans whose parents were once subsistence farmers. With policies geared to marketing, transport, seed supply, and fertilizer distribution the country could return to its former status as an exporter of food to the Central African region. A tiny faculty of agricultural and veterinary sciences is working to boost Angola's agricultural capacity and train extension workers in the Central Highlands. One policy is to re-introduce local seed and so diminish dependency on foreign genetically modified seed which is loaded with disadvantages for small scale subsistence farmers. Until a more urgent priority is given to revitalising the agrarian provinces, however, Angola is going to suffer real hardship. In 2006 the World Food Programme could only raise 19 of the 90 million dollars it required to feed 700,000 Angolans who had no access to domestic food supplies. Of these 220,000 are children enrolled in school feeding programmes. The United Nations is no longer able to feed nursing mothers or victims of tuberculosis. There are probably still 80,000 Angolan refugees living in neighbouring countries and past repatriation schemes have been supplied with flour, beans, oil and salt by a programme which is now closing down. In November 2006 the UN-funded air bridges which had supplied food to zones of acute malnutrition were withdrawn while the long-term government-funded programme of road transport restoration was in its infancy.

\section{The Meaning of Corruption}

One of the most delicate questions which a visiting politician must ask is "how far is 'corruption' a problem which is barring the road to prosperity and democracy?" The government has ratified the conventions on corruption of both the United Nations and also the African Union, yet defining corruption is not easy since it covers a whole gamut of influence peddling, embezzlement, and payment for services which ought to be free. Policemen are not well paid in Angola and the normal fee for passing a road check is 50 Kwanzas (35 pence). One suspects that a nurse might charge the same for bringing a bedpan to a bedridden patient. Further up the scale, members of the kleptocracy can earn good money by helping importers and exporters to expedite their business while delays and scandals in the docks fill the columns of the independent press. Opportunities for palm greasing appear to prevail and a spokesman for the MPLA, while not addressing the question of corruption at ministerial level, did talk of corruption relating to bureaucracy. The government is hoping to raise public administration salaries to 
deter illegitimate activity and some cases of petty corruption that have been investigated and are now in the hands of the attorney general.

For British visitors to ask questions about the privatisation of public assets - what Harold Macmillan described as the selling off of the family silver - is a little delicate since African politicians would probably see themselves as loyal followers of the dictates of the Thatcher Foundation. The independent Angolan newspapers would not see it that way, however, and a week before our arrival the front-page headline on one paper said "The Eduardo dos Santos Foundation is a canker at the heart of government." A free press can be very critical of the all-powerful head of state, though the story on the inside pages was an old one written by a distinguished, but now deceased, French political scientist. ${ }^{3}$ Even the more sober weeklies do not hesitate to point the finger at high-flying entrepreneurs:

"One day José Eduardo dos Santos will have to explain the byways through which his adult descendents passed to erect the enterprises which they now own and explanations will then have to be extended to other members of the clique currently in power."

In another impertinent story a fine picture of the president's daughter carried the caption "Isabel's finger-prints are beginning to be seen in the banking sector".

The links between money and power were illustrated in a story published on the day of our arrival. The firm of José Veríssimo Ltd which digs gravel and red sand at Macesso near Cabala recently paid the state $\$ 10,000$ for a quarrying licence but has now discovered a large Chinese-operated digger and four heavyduty tipper trucks stealing aggregate from the concession at night The Chinese foreman, Mr Young, drove a Nissan with the markings of the Gabinete de Reconstrução Nacional and the workers were protected by soldiers of the presidential household guard. The triangle of presidential guards, the office of national reconstruction, and Chinese entrepreneurs is normally dominated by General Hélder Vieira Dias, known by his nom de guerre of "Kopelipa". Such stories form the context for the question which Britain's visiting parliamentarians constantly asked: "Does corruption cause problems in Angola and if so what are the potential cures?"

\section{Cabinda, the elusive Eighteenth Province}

Another delicate question which our visiting politicians asked was "and what about Cabinda?" The answer on the front page of one of the weeklies we trawled was "Cabinda peace deal - an act of Strip-Tease". Forty per cent of Angola's oil comes from shallow-water wells whose huge gas flares can be seen off the shore of the former Portuguese enclave squeezed between ex-French and ex-Belgian Congo. Various factions of local politics try to argue that the province does not belong to Angola and that Portugal should belatedly give it its independence in the manner of East Timor, an Asian colony that was temporarily swallowed up by Indonesia for twenty-five years after the collapse of the Portuguese empire. The strip-tease involves peeling off layers of political influence in the enclave and giving politicians of greater or lesser influence and credibility seats at the mad

${ }^{3}$ See C. Messiant, L'Angola postcolonial, Paris, Karthala, 2008-2009, 2 vols. 
hatter's tea party in Luanda. Bringing Unita in from the cold did eventually end the war on the Angolan mainland and the assumption must be that a deal with Cabindans ought to be possible if the price is right. But 40 per cent of one and a half million barrels of oil a day (worth $\$ 60$ a barrel) is a lot of price. And watchful foreign neighbours might be willing to keep the pot on the boil in the hope of gaining a share of the spoils. The matter remains delicate and one brave journalist - later arrested by security police at Cabinda airport - claimed that the Cabindan signatory to a peace accord between Cabinda'

“'Forum for Democracy' and the Luanda government had no local legitimacy and, moreover, were wanted by Interpol in the United States. The journalist was also accused of writing words 'injurious to the reputation of the President of the Republic.'"

\section{The Luanda Urban Poverty Programme}

Politically this is the most important project to receive British funding. It is designed to create models of community self-reliance within the urban sphere of Luanda and to influence government policies and practices in key areas related to urban poverty. It aims to empower "the people" in a country where, for the last hundred years, citizens have assume that anything that is not done by the government - or on the instruction of the government - is liable to be illegal. This empowerment project is not only radical in terms of challenging the politics of centralisation but is also radical in that authority is being put into the hands of women as well as of men.

Although Luanda Urban Poverty Programme (Lupp) has been working in several sectors, one of the vehicles for giving people the confidence to take responsibilities into their own hands is focussed - as an example which might later be adopted and adapted in other spheres of local politics - on local water supplies. Water had been a key issue of controversy in Luanda since the seventeenth century. Until the early twentieth century water was brought down from the Bengo River by sea-going canoes but it is now brought by tanker lorries which negotiate the perilous mud lanes between the shanties to sell water very expensively by the gallon.

The city water supply, which delivers purified water erratically but virtually cost-free to the paved sections of the old inner city, is being expanded and extended to build a network of stand pipes (or stand posts) in the unpaved musseque communes. A network of 4,000 stand posts will eventually be needed for the four million new urban dwellers who have now settled permanently on the fringes of the old city of 400,000 inhabitants.

The Lupp has enabled 73 odd stand pipes to be built over five years. Each has a water management committee responsible for security, for maintenance and for the collection of revenue charges which are about one tenth of the price of the water delivered by the lorry entrepreneurs of the "wild economy". The committees are linked in communal level associations which provide solidarity and protection against possible inimical interference by politicians with private enterprise ambitions. Leaders chosen to represent each committee receive three months of training. When a problem arises an association can deal directly with the water 
provincial provider. Each committee is training personnel capable of solving some of the small technical problems associated with standpipes, a huge advance in the concept of self-reliance. Organised residents are now able to work on sanitation projects and joint street and rubbish clearing. The programme has resulted in the initiation of a culture of engagement and participation in the hope that local authorities will consult each community before making policy decisions.

Funding agencies should note at this point that the evolution of civil society in the communes in which Lupp is active has not been spontaneous and indigenous but has been sponsored by international humanitarian organizations. They therefore still need time to foster their sense of compete independence from their international progenitors.

Poverty reduction is the primary aim of the Lupp which draws on the strengths of CARE, One World Action, Save the Children, and Development Workshop all working under the umbrella of Britain's Department for International Development. A previous APPG visited the project's activities in Cacuaco, where survival in the all-important "informal" sector of commerce and artisanship was assisted by micro-credit schemes and in Kilamba Kiaxi where garbage collection and community lavatories were the projects designed to enhance municipal pride and participatory democracy. The 2006 visit went to two projects in Cazenga to see poverty reduction strategies at work on the ground. Lupp is very effectively testing models and methods of urban poverty reduction, helping local community organisations to collaborate with local municipal and communal government, facilitating dialogue with wider civil society organisations as well as with central government ministries, and not least creating crèches and consumer cooperatives to help women citizens. We were unable to see the poster campaign for community development which the Luanda provincial government had agreed to sponsor at the suggestion of Development Workshop - our twenty-five-year-old host agency which has so successfully pursued the policy of "engaging in preference to criticising" when inching administrators forward.

One question which has to be asked is whether a scheme pioneered in two of the northern municipalities of the city is now sufficiently robust to stand on its own feet and generate the intended multiplier effect. The answer is a unfortunately no, it is not. A few more years of experimentation are still needed. As will be explained in a later paragraph, success has been dramatic but a small, externally funded, audit role and umbrella of political protection is still required. Bilateral aid to Angola is slowly being withdrawn. The logical assumption is that with such considerable oil wealth, this country could not possibly be in need of much aid. Angola, however, has had only four years of peace, a peace which is not yet fully consolidated. It has a thirty year gap in its history to catch up on and the fact that the country ranks second from worst in the world for under-five mortality shows that oil is not necessarily the whole answer. Bilateral aid can be considered superior to aid channelled through large donor institutions whose sizeable bureaucracies can cause delay and expense.

\section{Urban Land Tenure}

While DFID, the British ministry for international development, has been sponsoring the introduction of the concept of democracy into the local government of 
the municipalities of Luanda, Christian Aid has been exploring the possibility of applying the rule of law to the field of city land tenure. Each policy would essentially be a first for Angola.

When Luanda underwent a ten-fold expansion - during the thirty post-colonial years of civil and interventionist warfare - pressures on land became intense. The old city does possess a colonial land register but access to it is so cumbersome that none but the most dedicated of legal beavers can find the relevant entries. In practice registered land, and the tenure of high-rise apartments, was "nationalised" during the austere Marxist decade of 1975 to 1985 and then "privatised" during the free-market decade of 1985-1995. During the colonial period the ownership of rental properties was overwhelmingly in the hands of senior army officers managing the expeditionary force from Portugal. In the cidade asfaltada of central Luanda that tradition seems to have been inherited by the senior officers of the national army.

In suburban and peri-urban Luanda land tenure is governed by community convention and tradition. The early twentieth-century African housing in the lower middle-class suburbs was build with brick walls, tiled roofs and proud little gardens. The peri-urban additions built of concrete blocks with zinc roofs, are less elegant but none-the-less substantial. Both types, however, impede the expansion of the rampant commercial sector fuelled by high oil prices and almost unlimited Chinese lines of credit. The government believes that it owns the land. The result has been conflict over land which has been almost as shocking as the suburban landclearances orchestrated by Robert Mugabe's so-called "veterans" in Zimbabwe, this despite the fact that the Angolan government has ratified the UN Habitat Convention. Angolan citizens can in theory obtain paper title but they only have been given only three years in which they may do so. To gain such a legal title, however, they must first obtain an identity card which can itself take up to two years.

The problem of defending the rights of householders to retain their properties at a time of rampant business development is acute. One briefing paper that was given to us on our arrival summed up the issues that confront the legal system thus

"Many seats on the Supreme Court remain vacant and a Constitutional Court, authorised by law in 1992, has not yet been established. In addition, the courts are crippled by the war and are perceived ineffective and untrustworthy by the few have access to them."

The system lacks the resource and independence to play an effective role and the legal framework is obsolete; much of the criminal and commercial code reflecting the colonial era with modifications from the Marxist era.

The more crude, if well-connected, developers in Luanda do not even pretend to search for legal ownership rights but pay armed policemen to issue eviction orders at the point of a gun. Some families who find themselves out on the street have traditional rights extending back over several generations. What they lack is title, or a document saying they have ownership of the land, a document which any government minister or army general can readily obtain. Other families find that their entire stock of financial assets, and their business creditworthiness, can be bulldozed to rubble overnight. Some breathing space in the process of land 
evictions might have been gained by the oxygen of international publicity which Amnesty International was able to provide. A civil society group, SOS Habitat, is also working to defend human rights specifically related to land and shelter. The group looks to raise the profile of the vulnerable peri-urban communities. But if one asks the average Luandan what the greatest threat to human rights is in the city the answer is always the same: it is the police who threaten us most.

Christian Aid is the Robin Hood of the international development agencies. Three years ago it hired Joseph Fiennes to demonstrate to first world television audiences the reality of poverty in the third world, as witnessed in Angola. But why, asked our Presbyterian peer, does the Angolan government - wedded as it is to wealth creation and the empowerment of the élite - desist from having this intrepid Protestant NGO drummed out of the Luanda forest. Christian radicalism, with a little protection from foreign publicity, takes on a dangerous role in Angola when defending human rights and supporting poverty alleviation.

Christian Aid works with a variety of partners in Angola with the aim of strengthening their ability to respond to the needs, rights and aspirations of poor Angolans and then share their experience with the government of Angola. Marginalised women and impoverished men are helped to hold decision-makers to account. Access to resources and the prevention of epidemics, including the AIDS epidemic, are key components of the programmes. During the recent cholera outbreak (which may have killed a thousand people in Luanda alone) the community bulletin Ecos da Henda advised slum-dwellers to bury their dead immediately without first washing the corpse - such is the level of detail in which NGOs can get involved. In the search for civic education programmes and leadership capacity-building it is local churches and local organisations (including trade unions, lobbying groups, charities, human rights groups and business associations) who are the key partners both in the dozen impoverished municipalities of Greater Luanda and in the rural provinces which have so far made few steps in the recovery from war. Christian Aid's emphasis so far is on Uíge province in the north-west (which was once the heartland of the opposition of FNLA, Kuando Kubango in the south-east (where Unita had its first and its last military bases) and Kwanza Sul, a once-rich coffee-growing district, not far from Luanda, which has attracted the attention of the new class of absentee black settlers. The British parliamentary delegation was able to meet several of Christian Aid's impressive partners.

We were not able to meet the Angolan association for justice, peace and democracy but their report (unfortunately only available in Portuguese) touched on many of our concerns. Prison reform comes top of the agenda and reports on the conditions in the Luanda gaols do not make savoury reading even if some of the accounts of physical punishments and deprivations are selected for their dramatic impact. Legal reform is also one of the urgent demands of the association which points out that sexual abuse does not feature in the Angola canon of criminal behaviour. Among the victimisations which are highlighted are the ostracism of HIV carriers against whom prejudice is very strong. The freedom of the press is now better than it ever was in Portuguese colonial times but protecting the freedom of expression can still be a risk. The case of the Cabinda peace process is 
a particularly sensitive issue and the journalist who was arrested in the province on 30 September 2006 was held for a month to warn him off criticising government policy.

\section{Farmers and Rural Development}

The oldest international development agency in Angola is the Development Workshop and is has worked for over a quarter of a century with non-governmental organisations and with ministries of international development, including the British and Canadian ones. While Angola's central government concentrates its energies on the third of the national population which now lives in and around the city of Luanda, the development agencies do not neglect the sixteen other mainland provinces in which the war-time legacies of poverty, illiteracy and disease are at least as acute as they are in the urban slums.

On the plateau of the central highlands farmers face a legal time-bomb. Their traditional legal rights of usufruct - land use - are not recognised by the national government which is sternly wedded to the bureaucratic concepts of paper documentation which it inherited from the old "fascist" regime of 1940 s colonialism. Farmers, primarily women but also men, have therefore been told that if they do not obtain paper title to their holdings, and also put up permanent rather than temporary farm buildings, they will be at risk of land expropriation for the benefit of absentee landlords who will come up from the lowland cities with governmentapproved paper titles.

Farmers who have neither the required identity cards nor the necessary literacy skills to begin the process of registering land claims are being given help as Development Workshop enables them to survey and measure their properties. This might be a first step to registering a claim in written law, as opposed to oral law, or it might give them leverage in negotiating the exchange of an existing plot for a comparable one elsewhere which administrators are more willing to release to the peasant sector.

Two completely contrasted opinions were given by witnesses to the highland agricultural scene. One said that the highlands were not sufficiently fertile to attract the attention of ex-generals and others who were anxious to rapidly enhance their post-war incomes by gaining private title to public land resources. The second opinion said that, on the contrary, it was the city bourgeois of the lowlands who were the greatest threat to the well-being of highland farmers. An independent journalist speculated that the number of former generals who were playing the field in the "wild" real estate market both in the city and in the provinces was more than five hundred. The group was told one story of a family who for generations had farmed cassava on a piece of land and used its mango trees for shade and fruit. When they recently went to check their crop after an absence of three days, they were denied access and told by the police that they could no longer grow food there.

There is also the issue of returning refugees and internally displaced persons. Those who decide to return to their land may now find it farmed by another family. No solution is offered centrally on how to resolve these conflicts. There is also the problem of clashing economic interests when pastoral farmers encroach 
upon land dedicated to arable farming. With the government trying to create large plantation-style farms in some provinces, the peasants of Angola worry about their future. We came across an interesting example of one northern region where colonial land expropriation had formerly been devoted to ranching and which is now being restored to its old settler-type economy by new urban investors bringing in Charolais beef cattle. We had no opportunity to see how well this was being matched to the interests and aspirations of the local crop-farming community.

\section{National Identity}

The question of national identity and of xenophobia was at the top of the political agenda during our visit. The president made a much publicised speech to announce that Portuguese was not merely the "official" language of Angola but also the "national" language of Angola. One third of the population, he said, spoke Portuguese as their mother-tongue, as the language of social intercourse, and not merely the language of employment. The vernaculars, he said, presented problems of national identification since some of them were spoken across the national boundaries by foreigners. Up-grading fluency in Portuguese was the order of the day and eighty television journalists were outraged to be told that they would have to present themselves to the Catholic University of Luanda to be examined in language competence. Fifty of them refused and risked losing their jobs while senior editors gained exemption by claiming that it would undermine their dignity to sit in an examination hall with their juniors. The foreigners with whom elite Angolans feel truly at home are the Brazilians and the Portuguese - "our cousins" as the national football team explained in Germany when drawn to play against their former colonial masters in the World Cup. But realists in the world of business recognise that English is the language of the future and that the xenophobic fear of Anglo-Saxons (and of Afro-Saxons) has to be overcome. The great ogre for some Angolans is South Africa and although Angola nominally belongs to Southern African Development Coordination Conference (SADC) no move towards economic integration in the southern African region is anticipated for the next ten years. The anxieties about South African business penetration is perhaps most sharply felt by the new generation of Unita generals who are beginning to get their feet under the table of the ownership class. It is they who most stridently fear the post-apartheid generation of black entrepreneurs who would like a slice of Angola's contracts in construction, telecoms, banking and the other booming sectors fuelled by high oil prices and soaring levels of well-head production.

In the matter of identity sport is a major political issue in Angola. A basketball team came home from a tournament in Japan to be welcomed with cash gifts of quarter of million dollars from the army chief of staff and a telecoms entrepreneur. Even more bizarrely Angola still has a national team which - like the old colonial Portuguese - plays hockey on roller-skates in the absence of ice. But far more significantly ten million Lusophone Angolans have just eclipsed a hundred million Nigerian Afro-Saxons by winning the right to host the next African Cup of Nations. To make this dream a reality hundreds of millions of government 
money will have to be invested in football stadia, tarred roads, night-clubs and hotel bedrooms. This sporting coup is probably more important to the government than any kudos it might gain from holding a country-wide general election. Indeed one cheeky observer thought that the prospect of "an election in two years time" which has been on the table since the 2002 cease-fire would now have to be put on hold until after the Africa Cup since the managerial capacity to deal with both is not available. Here we come 2010, emulating London's 2012 bid for the Olympics. ${ }^{4}$ 